\title{
Present pattern of antibiotic sensitivity of gonococcal strains isolated in Bombay
}

\author{
J. M. MOSES, ${ }^{1}$ M. S. DESAI, ${ }^{1}$ C. B. BHOSLE, ${ }^{2}$ AND M. S. TRASI ${ }^{3}$
}

From the (1) Department of Serology, V.D. Training Centre, F. F. Group of Hospitals, the

$\left.{ }^{2}\right)$ Department of Pathology, Grant Medical College, and the $\left(^{3}\right)$ Department of Dermato-Venereology,

f. F. Group of Hospitals, Bombay, India

When the progressive development of microbial resistance to antibiotics was becoming common knowledge, it appeared for at least 10 years that the two major venereal diseases were escaping the problem. This continues to remain essentially true as regards the sensitivity of $T$. pallidum to penicillin, but the same can certainly not be said of the gonococcus.

In a study of ninety strains isolated in 1944, Reyn, Korner, and Bentzon (1958) found that the minimum inhibitory concentration (MIC) of penicillin ranged from 0.0038 to $0.024 \mathrm{i} . \mathrm{u} . / \mathrm{ml}$. This high degree of gonococcal susceptibility in almost 100 per cent. of strains continued to be reported for the next 10 years by other workers (Lankford, 1945; Romansky and Robin, 1947; Schümmer and Hubbes, 1951; Marcuse and Hussels, 1954; Del Love and Finland, 1955). Thayer, Field, Magnusson, and Garson (1957), with strains isolated in 1955-56, were among the first to report that a significant proportion (22 per cent.) of their strains showed a decreased sensitivity to penicillin. A series of reports has since appeared indicating this trend in increasing percentages of gonococcal isolates (Cradock-Watson, Shooter, and Nicol, 1958; Curtis and Wilkinson, 1958; Reyn, Korner, and Bentzon, 1958; Chacko and Yogeswari, 1966; Reyn, 1969).

There are undoubted geographical differences in the sensitivity patterns of these organisms, and, from the epidemiological and other points of view, further widespread studies are desirable. In this respect the findings for strains isolated in 1961 in Ceylon and Manila (Reyn, 1969) are interesting, with 33 per cent. of strains from Ceylon less sensitive to penicillin, 25 per cent. less sensitive to tetracycline, and 12.5

Received for publication January 18, 1971 per cent. less sensitive to spiramycin as compared with 100,70 , and 25 per cent. respectively for strains from Manila. Similarly, from Madras in India, Chacko and Yogeswari (1966) found 45.6 per cent. of strains isolated in 1964-65 to be less sensitive to penicillin.

\section{Material and methods}

Sensitivity studies were conducted on 216 strains of $N$. की gonorrhoeae isolated at random from patients attending the Outpatients Department of the Department of $\vec{v}$ Venereology, J. J. Group of Hospitals, Bombay. All strains were isolated during late 1968 and 1969.

The isolations were carried out on a clarified chocolate agar medium (Steinberg and Mollov, 1942), using Difco's Bacto-Tryptose, meat extract, Difco's Bacto-agar, and 7.5 per cent. rabbit blood. The identity and purity of the isolates were then confirmed by staining, by the oxidase reaction, by failure to grow on ordinary media at room temperature, and by fermentation reactions. Sensitivity studies were performed on fresh isolates by a plate dilution technique, using a medium similar to that used for isolation but incorporating different concentrations of the various antibiotics as shown in Table $I$.

24-hour-old pure cultures of the test strains were suspended in $1 \mathrm{ml}$. sterile saline and subsequently adjusted to a constant opacity (approximately 3,000 million organisms $/ \mathrm{ml}$.). Each antibiotic slant was inoculated with a loopful of the suspension, using a $2 \mathrm{~mm}$. platinum loop. In this manner, for each test strain, a total of 38 slants was inoculated - six for penicillin and eight each for the other four antibiotics. The slants were then incubated at $36^{\circ} \mathrm{C}$. in McIntosh jars under 10 per cent. $\mathrm{CO}_{2}$ (introduced from a $\mathrm{CO}_{2}$-cylinder under manometric adjustment). Results were read after $48 \mathrm{hrs}$ and recorded as the minimum concentration of antibiotic required to produce complete inhibition of growth (MIC). With each day's testing, laboratory maintained gonococcal strains of known MIC values were also included to ensure standardization of working conditions and constancy of results.

TABLE I Antibiotic concentrations used in plate-dilution technique

\begin{tabular}{|c|c|c|c|c|c|c|c|c|}
\hline \multirow{2}{*}{$\frac{\text { Antibiotic }}{\text { Penicillin (i.u./ml.) }}$} & \multicolumn{8}{|c|}{ Concentrations } \\
\hline & 0.025 & 0.05 & $0 \cdot 10$ & 0.25 & 0.50 & $1 \cdot 0$ & & \\
\hline
\end{tabular}




\section{Results}

The distribution of sensitivity to penicillin of the 216 strains tested is presented in Table II. In the case of the nineteen strains showing MIC values less than $0.025 \mathrm{i} . \mathrm{u} . / \mathrm{ml}$. and the seventeen strains with MIC values greater than $1.0 \mathrm{i} . \mathrm{u} . / \mathrm{ml}$., no further attempt was made to determine their exact MIC values. Thus it is not possible to state the exact range of sensitivity in vitro of the 216 strains, although it is certainly more than 40 -fold.

The dotted line in Table II between the concentration values of 0.10 and $0.25 \mathrm{i} . \mathrm{u} . / \mathrm{ml}$., represents the dividing line between gonococcal strains which are sensitive to penicillin (MIC $<0.17$ i.u. $/ \mathrm{ml}$.) and those showing decreased sensitivity (MIC $>0.17$ i.u./ml.). This value of $0.17 \mathrm{i} . \mathrm{u} . / \mathrm{ml}$. is an approximation from the corresponding $\mathrm{IC}_{50}$ value for penicillin (viz. $0.088 \mathrm{i} . \mathrm{u} . / \mathrm{ml}$.) of Reyn (1969) on the assumption that the MIC value is approximately twice the $\mathrm{IC}_{50}$ value.

The findings in Table II, as presented in Fig. 1, show a 'two-peak' pattern in the distribution of sensitivity to penicillin, 0.05 and $0.50 \mathrm{i} . \mathrm{u} . / \mathrm{ml}$., giving a 10-fold range. Table III compares the 'peak values' in the distribution of sensitivity to penicillin in our strains with those reported by Reyn and others (1958) and Chacko and Yogeswari (1966).

The sensitivity distributions of the same 216 strains to the other four antibiotics are shown in Table IV. The dotted lines represent the dividing line between the sensitive and less sensitive strains. The corresponding MIC values for each antibiotic as shown in the Table are approximations from Reyn's IC $_{50}$ values

viz. spiramycin - $>0.95 \mu \mathrm{g} . / \mathrm{ml}$;

erythromycin - >1.0 $\mu \mathrm{g} . / \mathrm{ml}$;

tetracycline $->1 \cdot 13 \mu \mathrm{g} . / \mathrm{ml}$;

chloramphenicol - >5 $\mu \mathrm{g} . / \mathrm{ml}$.

Table IV shows that the ranges of in vitro sensitivities to these four antibiotics are for spiramycin more than 16-fold, erythromycin more than 32-fold, tetracycline 64-fold, and chloramphenicol 32-fold.

Fig. 2 shows the sensitivity distributions to spiramycin, erythromycin, tetracycline, and chloramphenicol. Like penicillin, both spiramycin and erythromycin show a tendency to produce the 'two-

TABLE II Distribution of sensitivity to penicillin in 216 strains

\begin{tabular}{|c|c|c|c|c|c|c|c|c|}
\hline MIC of penicillin (i.u./ml.) & $<0.025$ & 0.025 & 0.05 & $0 \cdot 10$ & $0 \cdot 25$ & 0.50 & $1 \cdot 0$ & $>1 \cdot 0$ \\
\hline $\begin{array}{l}\text { Number of strains } \\
\text { Percentage }\end{array}$ & $\begin{array}{l}19 \\
8 \cdot 8\end{array}$ & $\begin{array}{l}9 \\
4 \cdot 2\end{array}$ & $\begin{array}{l}43 \\
19 \cdot 9\end{array}$ & $\begin{array}{l}24 \\
11 \cdot 1\end{array}$ & $\begin{array}{l}17 \\
7 \cdot 9\end{array}$ & $\begin{array}{l}59 \\
27 \cdot 3\end{array}$ & $\begin{array}{l}28 \\
13 \cdot 0\end{array}$ & $\begin{array}{c}17 \\
7 \cdot 9\end{array}$ \\
\hline
\end{tabular}

TABLE III Comparison of 'peak' values in distribution of sensitivity to penicillin

\begin{tabular}{|c|c|c|c|c|}
\hline \multirow{2}{*}{ Authors } & \multirow{2}{*}{ Date } & \multicolumn{2}{|c|}{ MIC values (i.u./ml.) } & \multirow{2}{*}{ Range } \\
\hline & & 1 st peak & 2nd peak & \\
\hline Reyn and others & 1958 & 0.016 & 0.320 & 20-fold \\
\hline Chacko and Yogeswari & 1966 & 0.008 & 0.512 & 64-fold \\
\hline Present series & & 0.050 & 0.500 & 10-fold \\
\hline
\end{tabular}

T A B L E I V Distribution of sensitivity to other antibiotics of 216 strains

\begin{tabular}{|c|c|c|c|c|c|c|c|c|c|}
\hline \multirow{2}{*}{ Antibiotic } & \multicolumn{9}{|c|}{ Number of strains (per cent.) at different MIC values ( $\mu \mathrm{g} . / \mathrm{ml}$. ) } \\
\hline & $0 \cdot 125$ & $0 \cdot 25$ & 0.50 & $1 \cdot 0$ & $2 \cdot 0$ & $4 \cdot 0$ & $6 \cdot 0$ & $\mathbf{8 \cdot 0}$ & $>8 \cdot 0$ \\
\hline $\begin{array}{l}\text { Spiramycin } \\
\left(\mathrm{LS}^{\star}:>2.0 \mu \mathrm{g} . / \mathrm{ml} .\right)\end{array}$ & Nil & Nil & $\begin{array}{l}5 \\
(2 \cdot 3)\end{array}$ & $\begin{array}{c}41 \\
(19 \cdot 0)\end{array}$ & $\begin{array}{l}30 \\
(13 \cdot 9)\end{array}$ & $\stackrel{23}{(10 \cdot 7)}$ & $\begin{array}{l}61 \\
(28 \cdot 2)\end{array}$ & $\begin{array}{l}37 \\
(17 \cdot 1)\end{array}$ & $\begin{array}{l}19 \\
(8 \cdot 8)\end{array}$ \\
\hline $\begin{array}{l}\text { Erythromycin } \\
\left(\mathrm{LS}^{\star}:>2.0 \mu \mathrm{g} . / \mathrm{ml} .\right)\end{array}$ & Nil & $\begin{array}{l}20 \\
(9 \cdot 3)\end{array}$ & $\begin{array}{l}13 \\
(6 \cdot 0)\end{array}$ & $\begin{array}{l}23 \\
(10 \cdot 6)\end{array}$ & $\begin{array}{l}52 \\
(24 \cdot 1)\end{array}$ & $\begin{array}{l}25 \\
(11 \cdot 6)\end{array}$ & $\begin{array}{l}17 \\
(7 \cdot 9)\end{array}$ & $\begin{array}{l}34 \\
(15 \cdot 7)\end{array}$ & $\begin{array}{l}32 \\
(14 \cdot 8)\end{array}$ \\
\hline $\begin{array}{l}\text { Tetracycline } \\
\left.(\mathrm{LS})^{\star}:>2 \cdot 0 \mu \mathrm{g} . / \mathrm{ml} .\right)\end{array}$ & $\stackrel{3}{(1 \cdot 4)}$ & $\begin{array}{l}16 \\
(7 \cdot 4)\end{array}$ & $\begin{array}{l}33 \\
(15 \cdot 3)\end{array}$ & $\begin{array}{l}39 \\
(18 \cdot 0)\end{array}$ & $\begin{array}{l}65 \\
(30 \cdot 1)\end{array}$ & $\begin{array}{l}36 \\
(16 \cdot 7)\end{array}$ & $\begin{array}{l}17 \\
(7 \cdot 9)\end{array}$ & $\begin{array}{l}7 \\
(3 \cdot 2)\end{array}$ & Nil \\
\hline $\begin{array}{l}\text { Chloramphenicol } \\
\left(\mathrm{LS}^{\star}:>10.0 \mu \mathrm{g} . / \mathrm{ml} .\right)\end{array}$ & Nil & $\begin{array}{l}7 \\
(3 \cdot 2)\end{array}$ & $\begin{array}{l}13 \\
(6 \cdot 0)\end{array}$ & $\begin{array}{l}32 \\
(14 \cdot 8)\end{array}$ & $\begin{array}{l}55 \\
(25 \cdot 5)\end{array}$ & $\begin{array}{l}49 \\
(22 \cdot 7)\end{array}$ & $\begin{array}{l}39 \\
(18 \cdot 1)\end{array}$ & $\begin{array}{l}21 \\
(9 \cdot 7)\end{array}$ & Nil \\
\hline
\end{tabular}

$\star_{\text {LS }}=$ less sensitive 


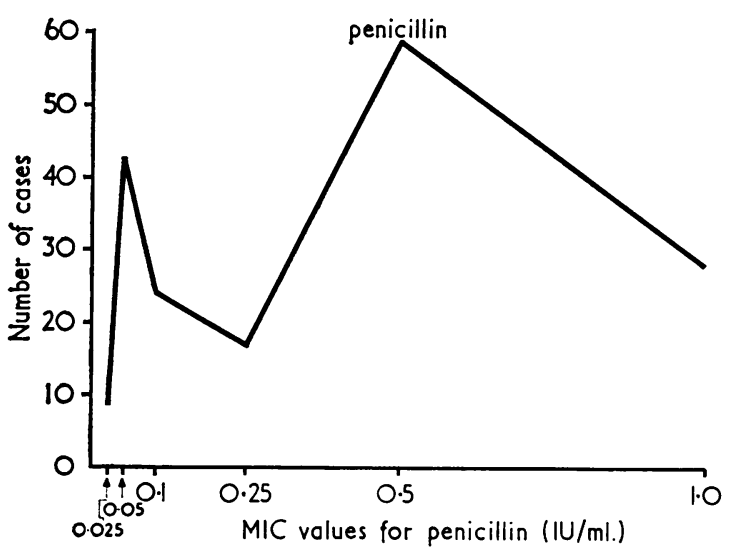

FIG. 1 Distribution of sensitivity to penicillin

peak' pattern. For spiramycin the two peaks occur at 1 and $6 \mu \mathrm{g} . / \mathrm{ml}$., and for erythromycin 2 and 8 $\mu \mathrm{g} . / \mathrm{ml}$. Tetracycline and chloramphenicol both gave single peaks at $2 \mu \mathrm{g} . / \mathrm{ml}$.

Table V classifies the 216 strains into two groups sensitive and less sensitive - against each of the five antibiotics tested. None of the strains could be described as showing decreased sensitivity to chloramphenicol. Surprisingly, it was spiramycin to which the largest number of strains (64.8 per cent.) were found to be less sensitive, whereas only 56 per cent. were less sensitive to penicillin, 50 per cent. to erythromycin, and 27.8 per cent. to tetracycline.

TABLE $\mathrm{V}$ Classification of response in vitro to various antibiotics

\begin{tabular}{|c|c|c|}
\hline \multirow{3}{*}{$\begin{array}{l}\text { Antibiotic } \\
\overline{\text { Penicillin }} \\
\left(\mathrm{LS}:^{\star} \geqslant 0 \cdot 17 \text { i.u. } / \mathrm{ml} .\right)\end{array}$} & \multicolumn{2}{|c|}{ Number of strains (per cent.) } \\
\hline & Sensitive & Less sensitive \\
\hline & $95 \quad(44)$ & $121 \quad(56)$ \\
\hline $\begin{array}{l}\text { Spiramycin } \\
\text { (LS: }>2 \mu \mathrm{g} . / \mathrm{ml} .)\end{array}$ & $76 \quad(35 \cdot 2)$ & $140 \quad(64 \cdot 8)$ \\
\hline $\begin{array}{l}\text { Erythromycin } \\
(\mathrm{LS}:>2 \mu \mathrm{g} . / \mathrm{ml} .)\end{array}$ & $108 \quad(50)$ & $108(50)$ \\
\hline $\begin{array}{l}\text { Tetracycline } \\
(\mathrm{LS}:>2 \mu \mathrm{g} . / \mathrm{ml} .)\end{array}$ & $156 \quad(72 \cdot 2)$ & $60 \quad(27 \cdot 8)$ \\
\hline $\begin{array}{l}\text { Chloromycetin } \\
\text { (LS: > } 10 \mu \mathrm{g} . / \mathrm{ml} \text {.) }\end{array}$ & $216 \quad(100)$ & Nil \\
\hline
\end{tabular}

$\star_{\mathrm{L} S \mathrm{~S}}=$ less sensitive

In a selected number of cases an attempt was made to correlate results in vitro with clinical behaviour in respect of penicillin. Thus, in 145 cases of acute gonococcal urethritis available for follow up studies, 47 were clinically classified as responsive to therapy

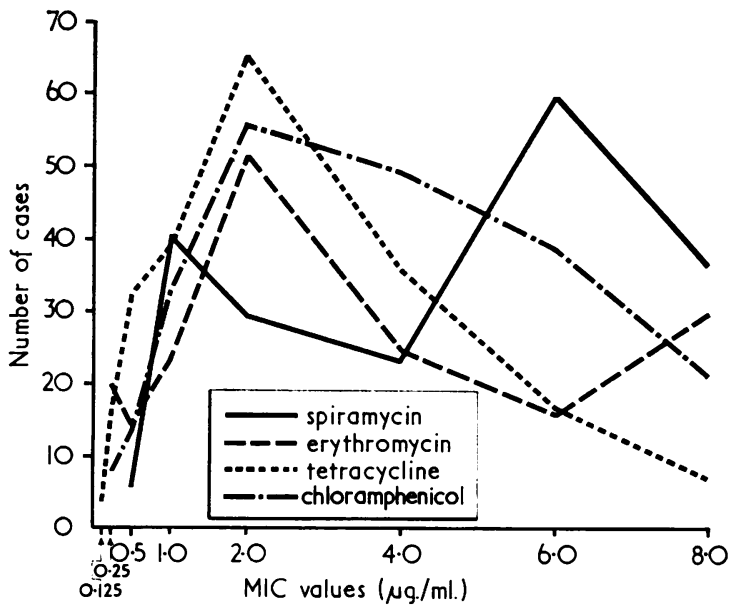

FIG. 2 Distributions of sensitivity to spiramycin, erythromycin, tetracycline, and chloramphenicol

while 98 showed diminished response as they did not $\overrightarrow{0}$ respond to standard treatment with 1.2 million i.u. procaine penicillin. The distribution of sensitivity to penicillin in these 98 cases is shown in Table VI; while 77 strains could be classified as less sensitive on the basis of in vitro testing, 21 strains could not. The degree of correlation between the results $\stackrel{\perp}{\perp}$ in vitro and the therapeutic response to penicillin in $\overrightarrow{\vec{O}}$ the 145 selected cases is shown in Table VII. The correlation is seen to be fairly high -80 to 90 per cent.

\section{Discussion}

The sensitivity patterns elaborated above are in respect of gonococcal strains isolated in 1968-69. Pre-1968 cultures were unfortunately not available to us in sufficient numbers to establish the changing patterns of gonococcal sensitivity, if any. Nor is there, as far as we are aware, any published information in this respect for the Bombay area (Maharashtra State, India).

Chacko and Yogeswari (1966), working with o strains isolated at random from patients in Madras (April, 1963, to September, 1965), found 45.6 per cent. with decreased sensitivity to penicillin. However, when this study was divided into two periods April, 1963, to September, 1964, and October, 1964, to September, 1965 - the incidence of strains with $\mathbb{D}$ decreased sensitivity was seen to rise steeply from? 23.4 to 60.4 per cent. It would be interesting to know whether the situation is static or whether further increases have been experienced in the Madras area, $\stackrel{?}{\mathscr{Q}}$ particularly as the incidence of 56 per cent. for the $\_$ 1968-69 Bombay collection is similar to that of 60.4 O per cent. for the 1964-65 Madras collection. 
TABLE VI Distribution of sensitivity to penicillin in 98 cases clinically classified as having a diminished response to penicillin therapy

\begin{tabular}{|c|c|c|c|c|c|c|c|c|}
\hline MIC of penicillin (i.u./ml.) & $<0.025$ & 0.025 & 0.05 & $0 \cdot 10$ & $0 \cdot 25$ & 0.50 & $1 \cdot 0$ & $>1 \cdot 0$ \\
\hline $\begin{array}{l}\text { Number of strains } \\
\text { Percentage }\end{array}$ & Nil & Nil & $\begin{array}{l}8 \\
8 \cdot 2\end{array}$ & $\begin{array}{l}13 \\
13 \cdot 2\end{array}$ & $\begin{array}{l}9 \\
9 \cdot 2\end{array}$ & $\begin{array}{l}40 \\
40 \cdot 8\end{array}$ & $\begin{array}{l}17 \\
17 \cdot 3\end{array}$ & $\begin{array}{l}11 \\
11 \cdot 3\end{array}$ \\
\hline
\end{tabular}

TABLE VII Comparison of sensitivity in vitro and clinical response to penicillin therapy (per cent.)

\begin{tabular}{|c|c|c|c|}
\hline \multirow{2}{*}{$\begin{array}{l}\text { Clinical } \\
\text { response }\end{array}$} & \multicolumn{2}{|c|}{ Results in vitro } & \multirow{2}{*}{ Total } \\
\hline & Sensitive & Less sensitive & \\
\hline \multirow{2}{*}{$\begin{array}{c}\text { Responsive } \\
\text { Diminished } \\
\text { response }\end{array}$} & $42 \quad(89 \cdot 4)$ & $5(10 \cdot 6)$ & 47 \\
\hline & $21 \quad(21.4)$ & $77 \quad(78 \cdot 6)$ & 98 \\
\hline Total & 63 & 82 & 145 \\
\hline
\end{tabular}

However, even with the scarcity of properly evaluated and documented evidence for India in particular and Asia in general, it may safely be concluded that the incidence of 'relative' resistance to penicillin has shown a sharp increase. This is equally true for most other parts of the world, although there are some reports of a reversal of this trend particularly from Northern Europe (Kallings and Gästrin, 1966; Ödegaard and Gjessing, 1967). Suvanamalik and Arnau (1964-1966) have reported strains with relative resistance to penicillin and other antibiotics among gonococci isolated in Bangkok, Thailand. Ho and Chang (1967) found a 30 per cent. incidence of strains with decreased sensitivity which is a sharp increase over the 5 per cent. incidence reported by Tai and Han (1960) for the same area (Taiwan, Formosa). In Australia, Smith and Levey (1967) have noted a 44 per cent. incidence of decreased sensitivity to penicillin among 104 gonococcal strains isolated in Sydney and Newcastle during 1966. Reyn (1969), testing 44 strains isolated during 1961 in Ceylon and the Philippines, found 63.6 per cent. with decreased sensitivity to penicillin, while in 43 strains isolated during 1967-68 in South-East Asia (Thailand, Hong Kong, Taiwan, and Vietnam) the incidence was 90 per cent.

With increasing incidence of relative resistance to penicillin an increase in the range of in vitro sensitivities follows. Table VIII, adapted with modifications from Guthe (1961) and from Chacko and Yogeswari (1966), clearly brings out this trend. It will also be seen that the percentage of strains with decreased susceptibility is significantly high in the Asian groups. Warren (1968) observed that the incidence of strains with decreased susceptibility was much higher in overseas infection groups than in his own 'local' material collected during 1958-1965 from the Southampton area in England.
The range of sensitivity in vitro to other antibiotics of the strains in our series is compared in Table IX with the findings of Reyn (1969) in her 1961 series from Ceylon and Manila and her 1967-68 series from South-East Asia. The marked rise in the number of strains with decreased sensitivity is once again obvious, even though it has not been possible to obtain clear 'basal' values for the 'pre-antibiotic' era with most other antibiotics as it has been with penicillin. This is only to be expected, as the introduction of most other antibiotics into general therapeutic use, even in a limited geographical locale, was irregular and haphazard, unlike the regular introduction of penicillin in the 1940s.

In the present series relating to the Bombay area, it is difficult to explain the high incidence of decreased sensitivity to spiramycin and erythromycin, as neither of these antibiotics has been widely used here. In this respect Reyn's observations on the close positive correlation between the inhibitory values of penicillin, spiramycin, and erythromycin are interesting. Both erythromycin and spiramycin belong to the macrolide group of antibiotics and are closely related chemically. In our experience also, multiresistance appears to be the rule, i.e. there is a strong positive correlation in the behaviour of a given gonococcal strain towards different antibiotics. Chasko and Yogeswari (1966) have suggested that decreased sensitivity to more than one antibiotic may be due to the existence of 'clones' within single strains of the organism, and the use of more than one antibiotic may tend to select clones resistant to these. However, it is unlikely that this 'clonal selection' is the only or even the most probable explanation, particularly because resistance to certain antibiotics is observed even when they have not been in common use. It is therefore more likely that multi-resistance is due to close chemical relationships between antibiotics.

The similarity of behaviour of certain antibiotics may also be reflected in the manner of development of resistance. Thus the 'two-peak' phenomenon in the distribution of sensitivity to penicillin reported be several workers (Cradock-Watson and others, 1958; Curtis and Wilkinson, 1958; King, 1958; Reyn and others, 1958; Chacko and Yogeswari, 1966) has been interpreted as a step-wise change in sensitivity, supporting the hypothesis that penicillin resistance 
TABLE VII I Comparison of sensitivity in vitro to penicillin of gonococcal strains isolated from 1944 to 1969

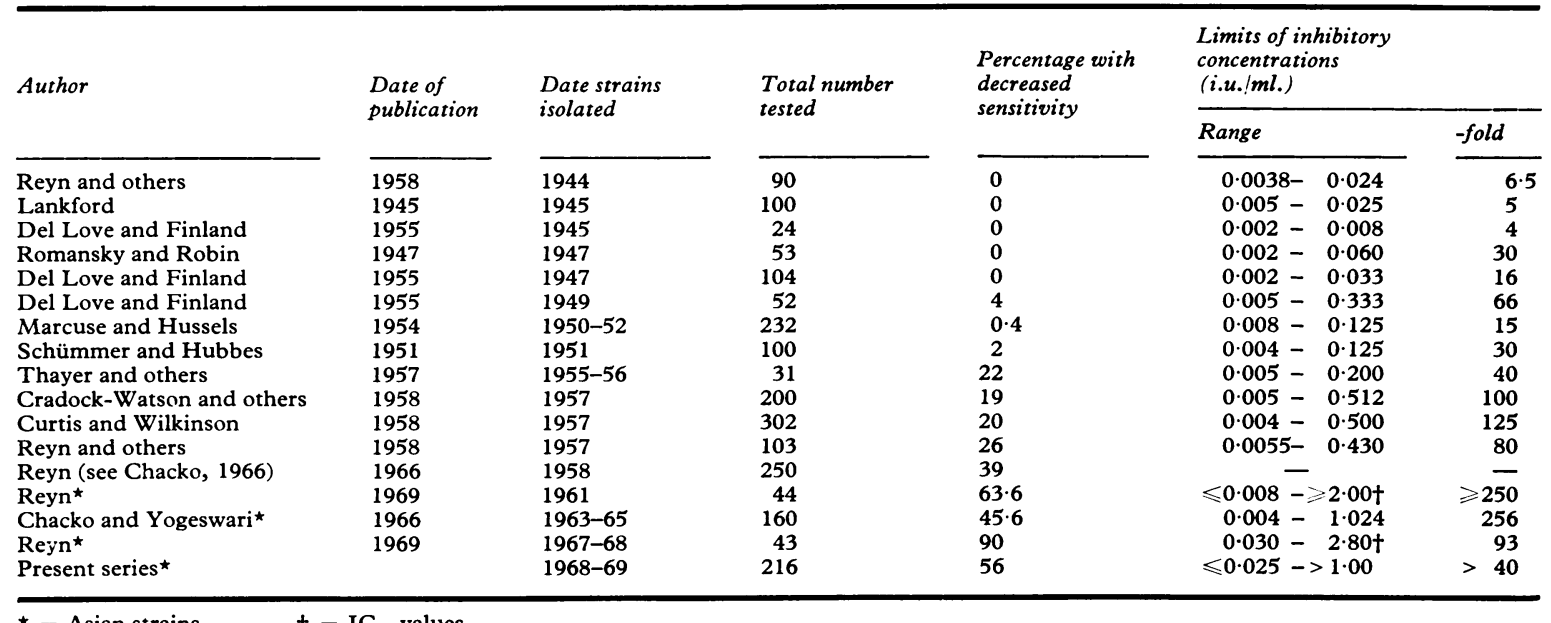

$\star=$ Asian strains

$t=\mathrm{IC}_{50}$ values

TABLE IX Comparison of sensitivity in vitro to some other antibiotics of gonococcal strains isolated in Asian countries during the last decade

\begin{tabular}{|c|c|c|c|c|c|c|c|c|c|}
\hline \multirow{4}{*}{ Antibiotic } & \multicolumn{9}{|c|}{ Limits of inhibitory concentrations, range, and percentage of strains with decreased sensitivity } \\
\hline & \multicolumn{6}{|l|}{ Reyn (1969) } & \multirow{2}{*}{\multicolumn{3}{|c|}{$\begin{array}{l}\text { Present series } \\
\text { Strains isolated in 1968-69 }\end{array}$}} \\
\hline & \multicolumn{3}{|c|}{ Strains isolated in 1961} & \multicolumn{3}{|c|}{ Strains isolated in 1967-68 } & & & \\
\hline & $\begin{array}{l}\text { Limits of } \\
\text { inhibitory con- } \\
\text { centrations } \\
(\mu \mathrm{g} . / \mathrm{ml} .)\end{array}$ & $\begin{array}{l}\text { Range- } \\
\text { fold }\end{array}$ & $\begin{array}{l}\text { Percentage } \\
\text { with } \\
\text { decreased } \\
\text { sensitivity }\end{array}$ & $\begin{array}{l}\text { Limits of } \\
\text { inhibitory con- } \\
\text { centrations } \\
(\mu \mathrm{g} . / \mathrm{ml} .)\end{array}$ & $\begin{array}{l}\text { Range- } \\
\text { fold }\end{array}$ & $\begin{array}{l}\text { Percentage } \\
\text { with } \\
\text { decreased } \\
\text { sensitivity }\end{array}$ & $\begin{array}{l}\text { Limits of } \\
\text { inhibitory con- } \\
\text { centrations }{ }^{\star} \\
(\mu \mathrm{g} . / \mathrm{ml} .)\end{array}$ & $\begin{array}{l}\text { Range- } \\
\text { fold }\end{array}$ & $\begin{array}{l}\text { Percentage } \\
\text { with } \\
\text { decreased } \\
\text { sensitivity }\end{array}$ \\
\hline $\begin{array}{l}\text { Spiramycin } \\
\text { Erythromycint } \\
\text { Tetracycline } \\
\text { Chloramphenicol } \dagger\end{array}$ & $\begin{array}{l}0.14-2.90 \\
0.11-\geqslant 1.77 \\
-\end{array}$ & $\begin{array}{l}21 \\
=16\end{array}$ & $\begin{array}{c}18 \cdot 2 \\
0 \\
45 \cdot 4 \\
0\end{array}$ & $\begin{array}{l}0 \cdot 168-3 \cdot 20 \\
\overline{0} \cdot 28-2 \cdot 60 \\
-\end{array}$ & $\frac{19}{9}$ & $\begin{array}{l}79 \\
79 \ddagger \\
74 \cdot 4 \\
25 \cdot 6 \ddagger\end{array}$ & $\begin{array}{l}0.50->8.0 \\
0.25->8.0 \\
0.125-8.0 \\
0.25-8.0\end{array}$ & $\begin{array}{r}>16 \\
>32 \\
64 \\
32\end{array}$ & $\begin{array}{c}64 \cdot 8 \\
50 \cdot 0 \\
27 \cdot 8 \\
0\end{array}$ \\
\hline
\end{tabular}

$\star \mathrm{IC}_{50}$ values

$\star \star M I C$ values

†Determinations by Disc-agar diffusion method in Reyn's series

$\ddagger$ Includes strains classified as moderately sensitive, less sensitive, and resistant by disc method

develops in a series of multiple steps. In the present study, both spiramycin and erythromycin also showed the 'two-peak' phenomenon, while tetracycline and chloramphenicol showed single peaks. These observations may also be explained by the chemical relationships between different antibiotics. Reyn's promised paper on such relationships is eagerly awaited (Reyn, 1969).

A question of interest to the clinician is that of the value of determinations of sensitivity in vitro in the treatment of the patient. The present study on 145 patients, though limited, showed a positive correlation between results in vitro and clinical response of 80 to 90 per cent. Thus, $89 \cdot 4$ per cent. of cases which responded completely to the routine penicillin treatment for gonorrhoea had yielded strains which were fully sensitive to penicillin in vitro, while 78.6 per cent. of those which did not respond to therapy yielded strains of decreased susceptibility.

\section{Summary and conclusions}

216 strains of $N$. gonorrhoeae, isolated at random from cases of acute gonococcal urethritis in the Bombay region, were tested in vitro by a plate-dilution technique for their sensitivity to penicillin, spiramycin, erythromycin, tetracycline, and chloramphenicol.

56 per cent. of these strains showed decreased susceptibility to penicillin, 64.8 per cent. to spiramycin, 50 per cent. to erythromycin, and 27.8 per cent. to tetracycline, but all were fully sensitive to chloramphenicol. A strong positive correlation was seen in the susceptibility of the strains to the different antibiotics, multi-resistance being the general rule. That this should occur with antibiotics which have 
not been in general use in this area is surprising, but is probably due to close chemical relationships between certain antibiotics.

Penicillin, spiramycin, and erythromycin showed a 'two-peak' pattern in sensitivity distribution while only single peaks were observed with tetracycline and chloramphenicol. This two-peak pattern has been interpreted as showing the development of resistance to penicillin in a series of steps. The similar behaviour of the two closely related members of the macrolide group of antibiotics, viz. spiramycin and erythromycin, is interesting.

The study has revealed a positive correlation between sensitivity in vitro and clinical response to standard penicillin therapy in 80 to 90 per cent. of cases.

\section{References}

Chacko, C. W., and Yogeswari, L. (1966) Ind. f. med. Res., 54, 823

Cradock-Watson, J. E., Shooter, R. A., and Nicol, C. S. (1958) Brit. med. F., 1, 1091

Curtis, F. R., and Wilkinson, A. E. (1958) Brit. F. vener. Dis., 34, 70

Del Love, B., JR., and Finland, M. (1955) Arch. intern. Med., 95, 66

GuTHE, T. (1961) Bull. Wld Hlth Org., 24, 297

Ho, T. J., and CHANG, S. S. (1967) Far East med. F., 3, 320

Kallings, L. O., and Gästrin, B. (1966) Nord. Med., 76, 800

KING, A. J. (1958) Lancet, 1, 651

LANKFORD, C. E. (1945) Amer. f. Syph., 29, 56

Marcuse, K., and Hussels, H. (1954) Derm. Wschr., 130, 1031

ÖdegaARd, K., and Gjessing, H. C. (1967) Brit. F. vener. Dis., 43, 284

ReYN, A. (1969) Bull. Wld Hlth Org., 40, 257

-, KoRnER, B., and BENTzon, M. W. (1958) Brit. $\mathcal{F}$. vener. Dis., 34, 227

Romansky, M. J., and Robin, E. V. D. (1947) Amer. F. Syph., 31, 271

SCHÜMMER, H., and HuBBes, A. (1951) Hautarzt, 2, 500

Smith, D. D., and LeveY, J. M. (1967) Med. F. Aust., 1, 849
Steinberg, P., and Mollov, M. (1942) f. Lab. clin. Med. 27, 656

Suvanamalik, S., and ARnaU, L. (1964-66) f. microbiol. Soc. Thailand, 8-10, 37

TAI, F. H., and HAN, S. H. (1960) f. Formosan med. Ass., 59, 1471

ThayeR, J. D., Field, F. W., Magnuson, H. J., and Garson, W. (1957) Antibiot. and Chemother., 7, 306

WARREN, R. M. (1968) Brit. f. vener. Dis., 44, 80

Aspect actuel de la sensibilité aux antibiotiques des souches de gonocoques isolées à Bombay

SOMMAIRE

La sensibilité in vitro a été étudiée pour 216 souches de $N$. gonorrhoea provenant d'urétrites gonococciques aigües et isolées par randomisation dans la région de Bombay. On utilisa la technique de dilution sur plaque in vitro vis-à-vis de pénicilline, spiramycine, érythromycine, tétracycline et chloramphénicol.

Parmi ces souches, 56 pour cent avaient une sensibilité diminuée à la pénicilline; 64,8 à la spiramycine; 50 à l'érythromycine et 27,8 à la tétracycline, mais toutes les souches étaient pleinement sensibles au chloramphénicol. On a trouvé une forte nette corrélation dans la sensibilité des souches vis-à-vis des différents antibiotiques et la multi-résistance est apparue comme une règle générale. Il est surprenant que ceci puisse survenir avec des antibiotiques qui n'ont pas été habituellement utilisés dans la région considérée, mais est probablement dû à des parentés chimiques étroites entre certains antibiotiques.

La pénicilline, la spiramycine et l'érythromycine montrèrent deux pics dans la distribution de la sensibilité, alors qu'un seul pic fut observé avec la tétracycline et le chloramphénicol. Ce profil à deux pics est considéré comme montrant le développement de la résistance à la pénicilline en une série d'étapes. Ce même comportemen $t$ de deux membres trés voisins du groupe des macrolides, c'est à dire spiramycine et érythromycine, est intéressant.'

L'étude a révélé une nette corrélation entre la sensibilitélin vitro et la réfonse clinique à un traiter-ent standard à la pénicilline dans 80 à $90^{\circ}$ four cent des cas. 